\title{
Enhancement of polyunsaturated fatty acid production under low-temperature stress in Cylindrotheca closterium
}

\author{
María Delfina Almeyda ${ }^{1,2}$. Paola G. Scodelaro Bilbao ${ }^{1,2} \cdot$ Cecilia A. Popovich ${ }^{1,2,3}$ - Diana Constenla ${ }^{4,5}$. \\ Patricia I. Leonardi ${ }^{1,2}$
}

Received: 18 September 2019 / Revised and accepted: 20 January 2020

(C) Springer Nature B.V. 2020

\begin{abstract}
Marine microalgae synthetize great amounts of essential metabolites such as fatty acids and amino acids. In addition, their exposure to stress factors can induce the overproduction of these desirable metabolites. Thus, in this work, we assessed the effect of low-temperature stress on lipid production and composition of the diatom Cylindrotheca closterium, in order to evaluate its potential as an alternative feedstock of essential polyunsaturated fatty acids (PUFAs). The alga was first cultured in a photobioreactor at $20{ }^{\circ} \mathrm{C}$ (control), and stressed by suddenly lowering the culture temperature, from $20{ }^{\circ} \mathrm{C}$ to $11{ }^{\circ} \mathrm{C}$, at the exponential (LTEP) or stationary (LTSP) growth phases. Neutral lipids (NLs) were the main lipid fraction of all conditions assayed, and their production was maximal at LTSP. Fatty acid analysis also showed that the greatest production of PUFAs was observed in the NL fraction at LTSP condition. In terms of essential fatty acids, the production of the omega- 3 fatty acids eicosapentaenoic acid and docosahexaenoic acid was similar in both treatments. The production of omega- 6 fatty acids was significantly higher in the LTSP condition due to an increase in arachidonic acid content. Sterols increased under both stress conditions, with a predominance of cholesterol. Considering that the LTSP condition elicited the best PUFA production, the amino acid composition was determined. The $46.81 \%$ of total amino acids were essential components for aquatic animals. These findings provide evidence of the potential of $C$. closterium as an alternative, sustainable source of sterols, essential fatty acids, and amino acids.
\end{abstract}

Keywords Low-temperature stress $\cdot$ Diatoms $\cdot$ Photobioreactor $\cdot$ Fatty acids $\cdot$ Sterols $\cdot$ Amino acids

Paola G. Scodelaro Bilbao

pscodela@criba.edu.ar

1 Centro de Recursos Naturales Renovables de la Zona Semiárida (CERZOS) (UNS-CONICET) Universidad Nacional del Sur-Consejo Nacional de Investigaciones Científicas y Técnicas, Bahía Blanca, Argentina

2 Departamento de Biología, Bioquímica y Farmacia, Universidad Nacional del Sur (UNS), Bahía Blanca, Argentina

3 Centro de Emprendedorismo y Desarrollo Territorial Sostenible (CEDETS) CIC-UPSO, Ciudad de Cali 320, Bahía Blanca, Argentina

4 Planta Piloto de Ingeniería Química (PLAPIQUI) (UNS-CONICET), Universidad Nacional del Sur-Consejo Nacional de Investigaciones Científicas y Técnicas, Bahía Blanca, Argentina

5 Departamento de Ingeniería Química, Universidad Nacional del Sur (UNS), Bahía Blanca, Argentina

\section{Introduction}

Microalgae are the main producers of eicosapentaenoic acids (EPA), arachydonic (ARA) and docosahexaenoic (DHA) in natural food chains (Adarme-Vega et al., 2012) and have therefore generated great interest in the food industries, nutraceuticals, and aquaculture foods (Miller et al. 2008; Bozarth et al. 2009; Yi et al. 2017). The main commercial source of these fatty acids is fish oil (Ward and Singh 2005; Maisashvili et al. 2015; Lazzarotto et al. 2018). The need to reduce this dependence on fish oil to avoid overfishing in the world's oceans and fluctuations in supply and cost is increasingly recognized (Turchini et al. 2009; Tocher 2015; FAO 2018). Efforts are therefore directed towards the assessment of renewable and sustainable alternative sources of essential fatty acids EPA, ARA, and DHA.

Diatoms are natural producers of essential omega-3 $(\omega-3)$ fatty acids such as EPA and DHA (Hamilton et al. 2014). 
During the exponential growth stage, these essential fatty acids are commonly found in the polar lipid fraction, being a part of the phospholipid structure (López-Alonso et al. 2000). However, during the stationary growth phase, PUFAs are stored as triacylglycerides (TAGs) in cytosolic lipid droplets (Boelen et al. 2017; Camacho-Rodríguez et al. 2018; Sanaa et al. 2018; Zulu et al. 2018). It has been reported that TAG synthesis also occurs when cell homeostasis is disrupted due to the action of a stressor (Borowitzka 2018; Wang et al. 2019). In addition to TAGs, some microalgae can synthetize other high-value products as proteins containing an important amount of essential amino acids (Brown 1991; Gong et al. 2019) and sterols (Rampen et al. 2010).

The biochemical composition of diatoms not only depends on the strain but also on the culture conditions employed. Their FA, protein, and sterol composition varies according to the growth stage, culture medium, and environmental conditions (salinity, light, and temperature) (Luo et al. 2015; Qiao et al. 2016; Gong et al. 2019). In particular, adaptation to low temperatures has been shown to increase the synthesis of polyunsaturated long-chain FAs in some diatoms (Qiao et al. 2016). However, there is little evidence showing how sudden changes in the culture temperature can affect PUFA production by diatoms.

Cylindrotheca closterium is a marine diatom with a high growth rate (Liang et al. 2002; Duong et al. 2015) that has been proposed as a promising candidate for biofuels (Wang et al. 2015) and for the production of high value pigments (Wang et al. 2018). In this species, PUFA-containing lipids have been shown to increase under nitrogen starvation (Wang et al. 2019). However, the effect of low-temperature stress on PUFA production has not been evaluated. The aim of this study was therefore to evaluate the effect of lowtemperature stress at two different growth stages on essential fatty acid production in C. closterium. The composition of sterols and amino acids was also analyzed in order to assess the nutritional value of the biomass.

\section{Materials and methods}

\section{Algal strain}

The marine diatom Cylindrotheca closterium (Ehrenberg) Reimann \& J. C. Lewin was isolated from Bahía Blanca Estuary $\left(38^{\circ} 45^{\prime} \mathrm{S}, 62^{\circ} 22^{\prime} \mathrm{W}\right)$. This is a tychopelagic diatom, which was identified according to Hasle and Syvertsen (1997) and Popovich and Marcovecchio (2008). Unialgal non-axenic cultures were established and maintained as culture stock, in $\mathrm{f} /$ 2 culture medium (McLachlan 1973) at $20{ }^{\circ} \mathrm{C}$, under $37 \mu \mathrm{mol}$ photons $\mathrm{m}^{-2} \mathrm{~s}^{-1}$ irradiance provided by fluorescent tubes, in a 12:12-h light/dark cycle.

\section{Culture in photobioreactor}

An initial inoculum containing $1.5 \times 10^{5}$ cells of $C$. closterium at the exponential growth stage was transferred to a cylindrical photobioreactor (Figmay 15L, FIGMAY S.R.L, Córdoba, Argentina) of $0.25 \mathrm{~m}$ diameter and $0.70 \mathrm{~m}$ height, containing $\mathrm{f} / 2$ culture medium to a final volume of $10 \mathrm{~L}$. The temperature of the culture was regulated by recirculating a cooling fluid through a glass coil, supplied by a thermostatic bath (Alpha RA 8, LAUDA, Germany).

Low-temperature stress experiments were performed as follows: (a) for the control condition, the temperature was maintained at $20 \pm 1{ }^{\circ} \mathrm{C}$ for 10 days; (b) for the low temperature at the stationary phase (LTSP) condition, the temperature was maintained at $20 \pm 1^{\circ} \mathrm{C}$ for 7 days and then lowered to $11 \pm 1{ }^{\circ} \mathrm{C}$ for the 3 remaining days; and (c) for the low temperature at the exponential phase (LTEP) condition, C. closterium cells was exposed to $20 \pm 1{ }^{\circ} \mathrm{C}$ for 3 days, and then kept at $11 \pm 1{ }^{\circ} \mathrm{C}$ for 7 days. Light intensity of $60 \mu \mathrm{mol}$ photons $\mathrm{m}^{-2} \mathrm{~s}^{-1}$ was provided by LED lamps, with a 12:12-h light/dark cycle. Cultures were supplied with $1 \%$ $\mathrm{CO}_{2}$ and maintained under continuous stirring at $9 \mathrm{rpm}$ by means of central paddles. Samples were taken every day to determine growth parameters. The biomass was harvested on day 10 through centrifugation at $3500 \times g$ for $15 \mathrm{~min}$, washed with phosphate saline buffer, lyophilized and stored at $80^{\circ} \mathrm{C}$.

\section{Specific growth rate, doubling time, and biomass dry weight determinations}

Cell density was determined by daily counts using a Sedgwick-Rafter chamber. The growth rate $\left(\mu ;\right.$ div. day $\left.{ }^{-1}\right)$, was estimated during the period of exponential growth by least squares fit to a straight line of the logarithmically transformed data (Guillard 1973). The time it takes a cell to double, doubling time (DT) (hours), was calculated as DT: $(1 / \mu) \times 24$. Cell volume was calculated using the formula of an elliptic prism (Hillebrand et al. 1999).

For biomass dry weight (DW), $10 \mathrm{~mL}$ of sample were collected daily, filtered through pre-conditioned and preweighed filters (Whatman GF/C) and washed with $10 \mathrm{~mL}$ distilled water. Then, filtered biomass was dried for $12 \mathrm{~h}$ at $70{ }^{\circ} \mathrm{C}$, cooled in a desiccator and weighed. Dry weight was obtained as the difference between the two values (Martín et al. 2016).

\section{Quantification of triacylglycerols and sterols}

Intracellular lipid droplets were detected through Sudan IV staining and observed in an optical microscope (DM2000, Leica Microsystems, Germany). Neutral lipids were detected by the fluorescent lipophilic probe, Nile Red (9-diethylamino- 
5H-benzo[alpha]phenoxazine-5-one), using a fluorescence microscope (Eclipse E800, Nikon, Japan) (Martín et al. 2016). In addition, TAG and sterol accumulation kinetics were evaluated according Scodelaro Bilbao et al. (2016). Briefly, lipids were extracted from C. closterium with chloroform:methanol $(2: 1, v / v)$ (Folch et al. 1957). A biphasic system was created through the addition of $0.05 \% \mathrm{CaCl}_{2}$ and centrifuged at $2000 \times g$ for $10 \mathrm{~min}$. The lower phase was recovered and dried under $\mathrm{N}_{2}$ atmosphere. TAG and sterols were separated through thin layer chromatography (TLC) and identified using the commercial standards triolein ( $2 \mathrm{~g} \mathrm{~L}^{-1}$ ) (Wienner Lab, Rosario, Argentina) and $\beta$-sitosterol (100 $\mathrm{g} \mathrm{mL}^{-1}$ ) (Sigma-Aldrich, USA), respectively. TLC was performed using silica gel plates (silica gel 60 G Merck, Germany). The mobile phase was n-hexane: diethyl ether $(80: 20 \mathrm{v} / \mathrm{v})$. The resulting bands were visualized with 2,7dichlorofluorescein. TAGs and sterols were scraped and eluted with chloroform/methanol/water $(5: 5: 1, v / v / v)$. Finally, through addition of $100 \mu \mathrm{L}$ of isopropyl alcohol, samples were quantified spectrophotometrically using commercial kit TAG color GPO/PAP and Colestat enzimático (Wienner Lab, Argentina). All reagents were of analytical grade and used without further purification.

\section{Gas chromatography analysis}

\section{Lipid fraction and fatty acid profile determination}

Lipid fractionation was performed from total lipid extracts (obtained as detailed in the "Gas chromatography analysis" section), using chloroform activated Silica Extraction Cartridges (PKG30 1 g, Enviro-Clean, USA) (Popovich et al. 2012). Neutral lipid (NL), glycolipid (GL), and phospholipid (PL) fractions were eluted, recovered, and evaporated to dryness under nitrogen. Finally, the weight of each fraction was determined.

To determine the fatty acid composition of total lipid extracts and lipid fractions, FAs were hydrolyzed and subjected to methylation. The resulting FA methyl esters (FAMEs) were analyzed through gas chromatography by a gas chromatograph (HP 4890D, Hewlett Packard, USA) equipped with a capillary SP2560 column (100 m, $0.25 \mathrm{~mm}$, and $0.2 \mu \mathrm{m})$ (Supelco Inc., USA). The equipment also contained a split/ splitless injector and a flame-ionization detector, both at $260{ }^{\circ} \mathrm{C}$. Data were analyzed using the HP3398A GC Chemstation Software (Hewlett Packard, USA). The Supelco FAME 10 mix 37 (CRM47885, Supelco Inc., USA) certified standard was used to identify FAMEs. Fatty acids content ( $\mathrm{g}(100 \mathrm{~g} \text { biomass })^{-1}$ ) was estimated from $\%$ of total FAMEs (Batista et al. 2013; Bonfanti et al. 2018). The conversion factors $\mathrm{F}$ were calculated according to Weihrauch et al. (1977), based on published information by Yu et al. (2009), Yao et al. (2015) and Yang et al. (2017).

\section{Sterol extraction and identification}

Sterols were extracted and identified as previously described in the "Gas chromatography analysis" section. The resulting dried extract was silylated with SIGMA SIL-A following the manufacturer's instructions (Sigma-Aldrich, USA). Separation and identification of sterols was carried out according to methods described by the International Olive Council (IOC, 2001) in a gas chromatograph (7820A, Agilent, USA) equipped with a $30 \mathrm{~m}$ capillary column of $0.25 \mathrm{~mm}$ i.d. and $0.2 \mu \mathrm{m}$ film thickness (SE 54, Supelco Inc., USA) as in Scodelaro Bilbao et al. (2016). An internal standard of 5- $\alpha$ cholestan-3- $\beta$-ol (Sigma-Aldrich, Switzerland) $\left(2 \mathrm{mg} \mathrm{mL}^{-1}\right)$ was used.

\section{Protein extraction}

Proteins from C. closterium were extracted using a lysis buffer (100 mM Tris $\mathrm{HCl}$ (pH 7.5), 300 mM NaCl, 4 mM EDTA, 4 mM EGTA, $0.2 \%$ Triton X-100, 2\% Nonidet P-40). Samples were vortexed vigorously and centrifuged for $15 \mathrm{~min}$ at $14,000 \times \mathrm{g}$ to remove insoluble material and unbroken cells. The colorimetric Bradford reaction (Bradford, 1976) was performed in an aliquot of the resulting supernatant using bovine serum albumin as standard.

\section{Amino acid profile determination}

Cylindrotheca closterium samples consisting of $6 \mathrm{mg}$ of lyophilized material were hydrolyzed by the addition of $1 \mathrm{~mL}$ of methanesulfonic acid $4 \mathrm{~N}$ (containing $0.2 \%(w / v)$ tryptamine) at $115^{\circ} \mathrm{C}$ for $22 \mathrm{~h}$ in vacuum-sealed tubes. The resulting freeamino acids were separated through cationic exchange chromatography using an automatic amino acid analyzer (Biochrom 30, GE-Healthcare Life Sciences, UK), sodium citrate buffers of different final $\mathrm{pH}(\mathrm{pH}=2.2,3.2,4.25$, and 6.45) and $0.4 \mathrm{M}$ of sodium hydroxide ( $\mathrm{pH}=13.6$ ) following the manufacturer's instructions. The resulting extract was then re-derivatized using of ninhydrin and products were detected through visible spectrophotometry at $570 \mathrm{~nm}$ and $440 \mathrm{~nm}$. Finally, amino acids were identified through comparison of retention times of amino acid commercial standards (18AA-Sigma and individual standards for L-methionisulfone, L-norleucine, L-methioninsulfoxide, Ltryptophan, and L-ornithine). In addition, quantification was performed using L-norleucine as internal standard (Simpson et al. 1976; Brown 1991).

\section{Statistical analysis}

One-way ANOVA and Tukey tests were used to analyze differences among treatments using software INFOSTAT (Di Rienzo et al. 2018). The significance level was set at $p<0.05$. 


\section{Results}

The growth rate and biomass kinetics of Cylindrotheca closterium at $20^{\circ} \mathrm{C}$ and under the two low-temperature stress conditions (LTSP and LTEP) are shown in Fig. 1 and Table 1. As can be seen in Fig. 1a, C. closterium followed the same growth kinetics under all the conditions assayed. Cells grew exponentially up to day 4 , when they reached the stationary growth phase, lasting until day 10. Although the final cell density of control and LTSP conditions was similar $(p>0.05)$, it was significantly lower when low-temperature stress was applied at the exponential growth phase (LTEP) $(p<0.05)$ (Fig. 1a). In terms of cell volume, the highest values were observed under LTEP and LTSP conditions $(p<0.05)$ (Table 1). The growth rates $(\mu)$ and doubling times (DT) revealed no statistically significant differences between the conditions assayed $(p>0.05)$ (Table 1).

Biomass kinetics showed a two-day lag phase under all the conditions tested. The largest biomass production occurred at day 6 (LTEP) and day 8 (control), followed by a marked decrease up to day 10 . Under the LTSP condition, however,

a
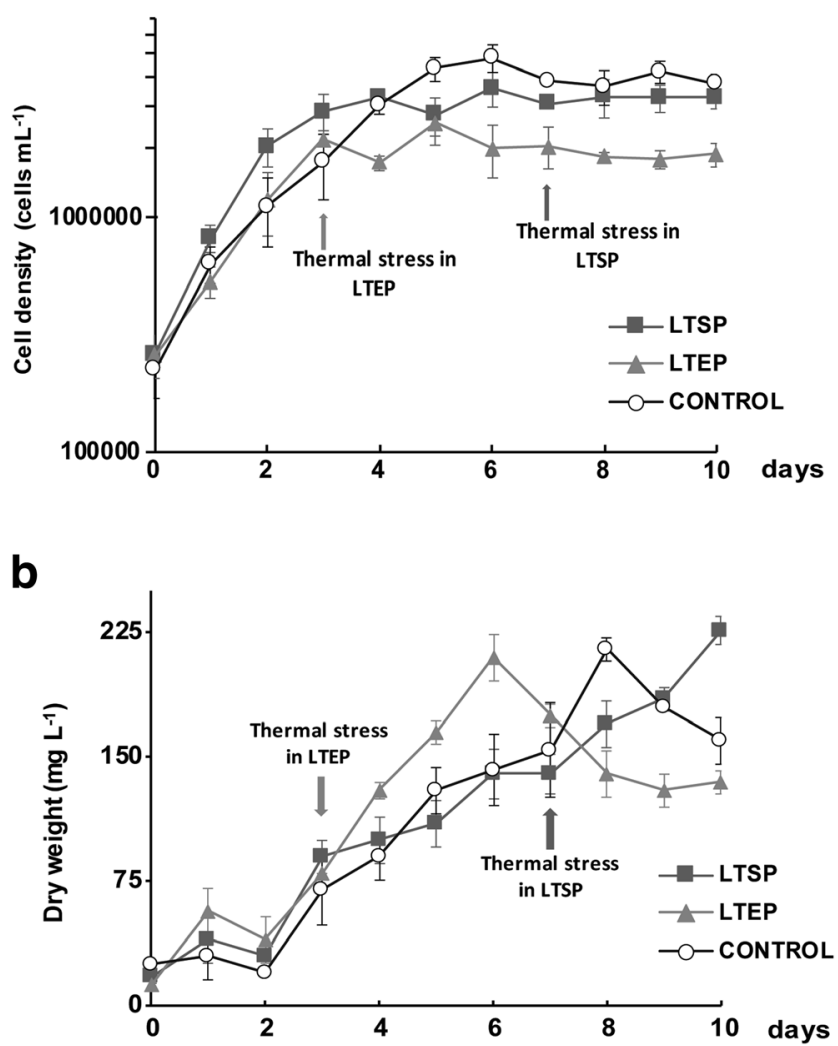

Fig. 1 Growth and biomass production of C. closterium in photobioreactor. a Cell density (cells $\mathrm{mL}^{-1}$ ) and b biomass kinetics (mg of dry weight $\mathrm{L}^{-1}$ ) for control, LTSP (low-temperature stress applied at stationary phase), and LTEP (low-temperature stress applied at exponential phase). Values are represented as the average \pm standard deviation $(n=3)$ the largest biomass production was observed on day 10 with no subsequent decrease in biomass production (Fig. $1 \mathrm{~b}$ and Table 1).

Total lipids reached their maximum values $(28 \%$ dry weight) under control and LTSP conditions, and $\approx 20 \%$ dry weight under the LTEP condition. With respect to lipid fractions (\% of total lipids), the NL was quantitatively the main fraction, followed by GL and PL under all conditions (Fig. 2a). The different temperature stress conditions did not affect the lipid fraction distribution with respect to total lipids $(p>0.05)$ (Fig. 2a). However, when the values were expressed as $\mathrm{mg} \mathrm{L}^{-1}$, NL production was significantly higher under the LTSP condition (Fig. 2b). TAG accumulation kinetics showed the highest TAG production (in $\mathrm{mg} \mathrm{L}^{-1}$ ) at the end of the stationary growth phase. However, the highest TAG values were obtained under LTSP stress condition on day 10 (Fig. 3a). This effect was also evidenced through the observation of cells under an optical microscope, where C. closterium cells exhibited numerous small lipid droplets dispersed in the cytoplasm by day 4 (exponential growth phase), whereas two or three larger lipid droplets were observed on day 10 of culture (stationary growth phase) (Fig. $3 \mathrm{~b}$ and c).

The lipid composition of C. closterium cells in terms of total fatty acids is shown in Table 2. Gas chromatography analysis revealed an increase in PUFAs, at the expense of a reduction in the relative percentage of SFA in response to low temperature stress, regardless of the phase in which it was applied. In addition, the percentage of PUFAs was significantly higher under the LTEP condition than under the LTSP condition, attributable mainly to eicosapentaenoic (EPA), whereas arachidonic (ARA) only increased under the LTSP condition. The decrease in the total percentage of SFA was mainly due to palmitic and stearic acids. The total percentage of monounsaturated fatty acids (MUFAs) only increased under the LTSP condition, owing to the role of palmitoleic acid. However, when these results were expressed in terms of production ( $\left.\mathrm{g}(100 \mathrm{~g} \text { biomass })^{-1}\right)$, both temperature-stress conditions showed a similar increase in the amount of PUFA that was above the level found in the control (Fig. 4a). The amount of $\omega$-3, increased from 1.92 to $2.96 \mathrm{~g}$ (100 g biomass $)^{-1}$ under both LTSP and LTEP conditions (Fig. 4b), mainly due to an increase in EPA and DHA (Fig. 4c). In terms of essential FAs, EPA and DHA production was similar under the two stress conditions. In the case of $\omega-6$, its production ( $g$ $\left.(100 \mathrm{~g} \text { biomass })^{-1}\right)$ was significantly higher under the LTSP condition. This was due to an increase in the level of ARA detected under this temperature condition.

The FA composition of each lipid fraction was analyzed and changes in the relative proportions (\% of total FAMEs) of SFAs, MUFAs, and PUFAs were observed (Table 3). For the LTSP condition, the amount of SFAs and PUFAs in the NL fraction decreased with respect to the control, at the expense of an increase in MUFAs. In the NL fraction of the LTEP 
Table 1 Specific growth rate $(\mu)$, doubling time (DT), and biomass production of $C$. closterium under control, LTSP (low-temperature stress at stationary phase) and LTEP (low-temperature stress at exponential phase) conditions. Values are expressed as an average \pm standard deviation $(n=3)$. Statistically significant differences $(p<0.05)$ in rows are indicated with different letters. *Final values at day 10 of culture

\begin{tabular}{llll}
\hline & Control & LTSP & LTEP \\
\hline Maximum growth rate $\left(\right.$ div day $\left.^{-1}\right)$ & $1.13 \pm 0.40 \mathrm{a}$ & $1.30 \pm 0.20 \mathrm{a}$ & $1.05 \pm 0.30 \mathrm{a}$ \\
Doubling time $(\mathrm{h})$ & $23.75 \pm 10.47 \mathrm{a}$ & $18.75 \pm 2.64 \mathrm{a}$ & $24.11 \pm 6.36 \mathrm{a}$ \\
Cell density $\left(\text { cells } \mathrm{mL}^{-1}\right)^{*}$ & $3,723,040 \pm 334,905 \mathrm{c}$ & $3,269,280 \pm 204,404 \mathrm{~b}$ & $1,864,667 \pm 210,308 \mathrm{a}$ \\
Cell volume $\left(\mu \mathrm{m}^{3}\right)^{*}$ & $86.03 \pm 31.84 \mathrm{a}$ & $144.29 \pm 34.61 \mathrm{~b}$ & $153.38 \pm 44.89 \mathrm{~b}$ \\
Biomass production $\left(\mathrm{mg} \text { dry weight } \mathrm{L}^{-1}\right)^{*}$ & $160 \pm 14 \mathrm{~b}$ & $226 \pm 08 \mathrm{c}$ & $135 \pm 07 \mathrm{a}$ \\
\hline
\end{tabular}

condition, the proportion of SFAs also decreased but was accompanied by an increase in MUFAs and PUFAs. The maximum values of PUFAs were found in the GL fraction, with values of $26.61 \%$ and $22.71 \%$ of total FAMEs for the LTEP and LTSP conditions, respectively. Nevertheless, when these values were expressed as $\mathrm{mg}(100 \mathrm{~g} \text { biomass })^{-1}$, the results clearly revealed that neutral lipids were quantitatively the most important FA source. The maximum production of PUFAs was observed in the NL fraction of the LTSP
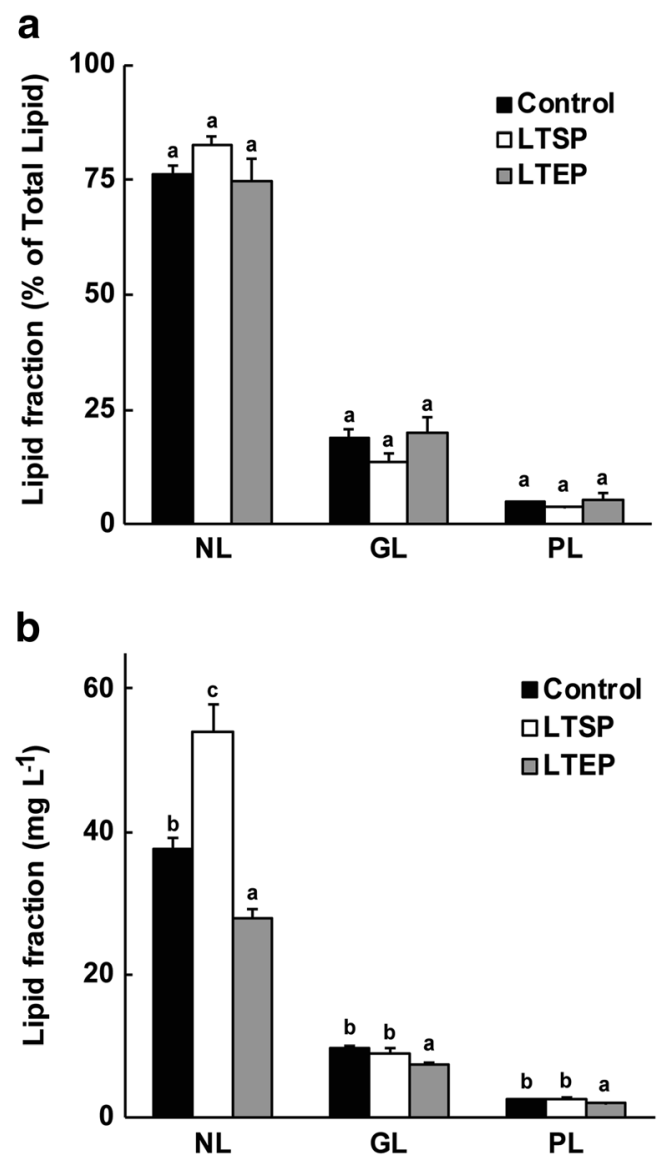

Fig. 2 Effect of culture temperature on C. closterium lipid fractions. a Relative percentage (\% of total lipids) of neutral lipids (NL), glycolipids (GL), and phospholipids (PL) and b C. closterium lipid fractions $\left(\mathrm{mg} \mathrm{L}^{-1}\right)$. Values are shown as averages $( \pm \mathrm{SD})(n=3)$. Different letters (per lipid fraction) represent significant differences $(p<0.05)$ condition, reaching a value of $2554 \mathrm{mg}$ (100 g biomass $)^{-1}$. Table 4 shows the essential FA content of each lipid fraction. When the results were expressed as \% of total FAMEs (left column), the highest increases of $\omega-3$ and $\omega-6$ with respect to control were detected in the GL fraction of the LTEP condition. However, in terms of production ( $\left.\mathrm{mg}(100 \mathrm{~g} \text { biomass })^{-1}\right)$, the most important source of $\omega-3$ and $\omega-6$ FAs was the NL fraction, in all the conditions tested. EPA content increased significantly under both temperature treatments, reaching values of 1252 and $1339 \mathrm{mg}$ (100 g biomass $)^{-1}$ for LTSP and LTEP, respectively, with no significant differences between these two conditions $(p>0.05)$. The highest DHA and ARA contents were detected in the dominant lipid fraction (NL) under LTSP.

Finally, the $\omega-3$ and $\omega-6$ FA contents (\% of total FAMEs) obtained from $C$. closterium cells grown under the LTSP condition with the values reported for different commonly used fish oils were compared (Table 5). In this way, C. closterium showed the highest value of ARA, a similar content of EPA and a lower value of DHA than those reported in fish oils.

With respect to $C$. closterium sterol content, their spectrophotometric quantification showed that low-temperature stress induced either at the exponential or stationary growth phases induced a similar increase in sterol content (Fig. 5a). Cholesterol and the phytosterols brassicasterol, stigmasterol, $\Delta$ 5-23-stigmastadienol, clerosterol, $\beta$-sitosterol, $\Delta 5$-24stigmastadienol, and $\Delta$-stigmastenol were the major sterols found under all the conditions assayed. Cholesterol was the main sterol found, representing 41,76 , and $57 \%$ of total sterols under control, LTSP and LTEP conditions, respectively (Fig. 5b). The major increase thus being under the LTSP condition. Although brassicasterol was the main phytosterol found under the control condition representing $32 \%$ of total sterols, its content was lower under the two thermal stresses assayed (Fig. 5b).

The effect of low-temperature stress on the protein content of $C$. closterium biomass was determined spectrophotometrically. The LTSP condition exhibited similar protein content (mg $\mathrm{g}^{-1}$ biomass) as the control, whereas when the stress was applied at the exponential growth phase, the amount of proteins was significantly higher than under the other two 
Fig. 3 Time-response analysis of C. closterium lipid production. a Spectrophotometric quantification of TAG $\left(\mathrm{mg} \mathrm{L}^{-1}\right)$ after 2, 4, 7, and 10 days of culture under control, LTSP, and LTEP temperature conditions. Values are represented as the averages $( \pm \mathrm{SD})(n=3)$. Different letters represent statistically significant differences $(p<0.05)$ between conditions. Intracellular lipid droplets of $C$. closterium cells exposed to low-temperature stress at the stationary growth phase (LTSP) and stained with $\mathbf{b}$ SUDAN IV and with c Nile Red

a

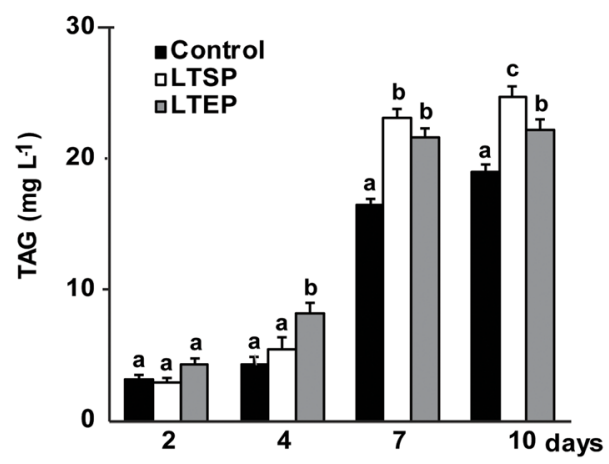

b

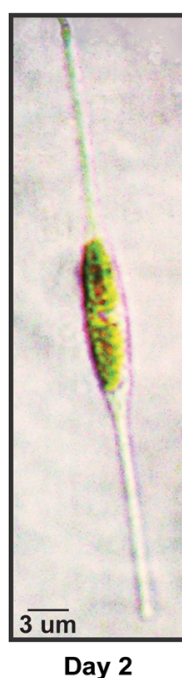

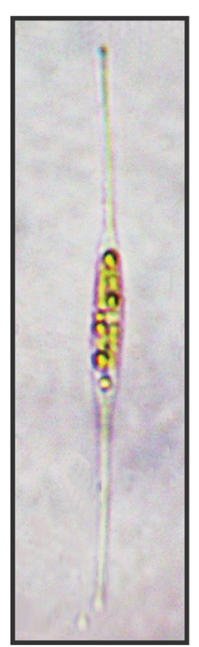

Day 4

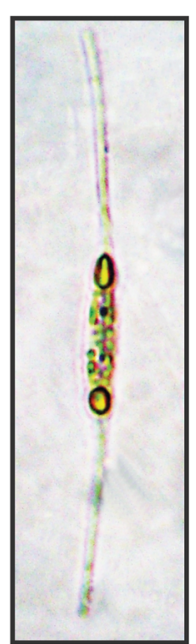

Day 7

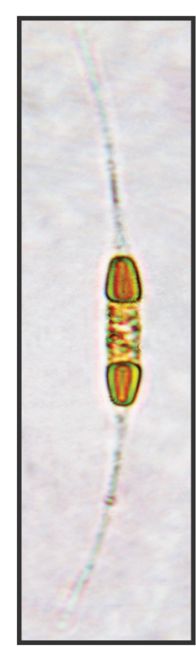

Day 10

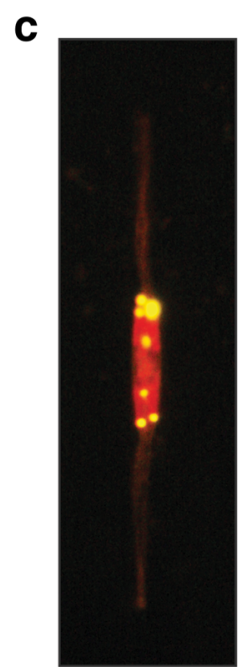

Day 4

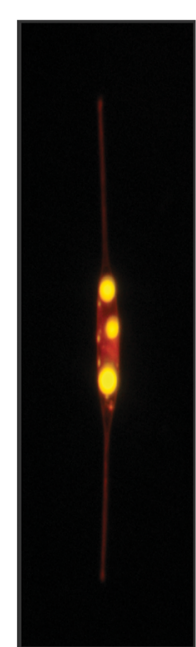

Day 10 conditions assayed (Fig. 6a). Taking into account that under the LTSP condition elicited the best production in terms of essential FAs, this condition was selected for the analysis of the amino acid profile (AA). Total AA content was $16.5 \mathrm{~g}$ (100 g biomass $)^{-1}$. Essential amino acids (EAA) for aquatic animals represented $46.81 \%$ of the total AA (Fig. 6b). Except for tryptophan, all essential amino acids were present in C. closterium, the major ones being leucine, valine, phenylalanine and lysine (Table 6). The highest AA relative amounts corresponded to glutamate and aspartate, with values of $11.90 \%$ and $9.84 \%$ of total AA, respectively (Table 6).

\section{Discussion}

The marine diatom C. closterium has been reported to have good growth performance and higher biomass production than other diatom species (Liang et al. 2002; Duong et al., 2015; Wang et al. 2018). In the present study, the specific growth rate was in the range reported for other strains of $C$. closterium (Wang et al. 2015; Demirel 2016; Erdoğan et al., 2016) and higher than that reported for other native marine diatoms from Bahía Blanca Estuary (Popovich et al. 2012). In addition, although low-temperature exposure decreased cell density, it rapidly increased cell volume, resulting in an increased biomass production under both stress conditions. These results agree with those found by Montagnes and Franklin (2001), who reported that low temperatures can induce a decrease in the growth rate of diatoms together with an increase in their cell volume.

Diatoms induce the synthesis and storage of lipids under diverse stress conditions (e.g., high light intensity, nutrient deficiency, and temperature) (Lombardi and Wangersky 1995; Zulu et al. 2018). Cylindrotheca closterium showed higher lipid content when low-temperature stress was applied at the stationary phase than when it was applied at the exponential phase, where the total lipid yield was negatively affected. In addition, the amount of lipids produced by C. closterium under the LTSP condition was higher than that reported for other strains of Cylindrotheca cultured in $\mathrm{f} / 2$ medium at $22{ }^{\circ} \mathrm{C}$ and harvested in the stationary growth phase (Liang et al. 2002) or at the end of exponential growth phase 
Table 2 Fatty acid profiles (as \% of total FAMEs) of C. closterium. Control, LTSP (low-temperature stress at stationary phase), LTEP (lowtemperature stress at exponential phase). Table shows means \pm standard deviation $(n=3)$, and the different letters in rows stand for statistically significant differences $(p<0.05)$ between temperature conditions

Fatty acids

\begin{tabular}{lll}
\hline Control & LTSP
\end{tabular}

Saturated (SFA)

$\begin{array}{llll}\text { C 14:0 } & 10.46 \pm 0.46 \mathrm{ab} & 10.90 \pm 0.15 \mathrm{~b} & 10.18 \pm 0.27 \mathrm{a} \\ \text { C 15:0 } & 0.38 \pm 0.04 \mathrm{a} & 0.38 \pm 0.01 \mathrm{a} & 0.73 \pm 0.02 \mathrm{~b} \\ \text { C 16:0 } & 31.56 \pm 0.48 \mathrm{c} & 24.78 \pm 0.11 \mathrm{~b} & 21.76 \pm 1.19 \mathrm{a} \\ \text { C 17:0 } & 0.09 \pm 0.02 & \text { nd } & \text { nd } \\ \text { C18:0 } & 3.86 \pm 0.15 \mathrm{c} & 0.50 \pm 0.05 \mathrm{~b} & 0.35 \pm 0.03 \mathrm{a} \\ \text { C 20:0 } & 0.38 \pm 0.02 \mathrm{c} & 0.14 \pm 0.01 \mathrm{~b} & 0.10 \pm 0.01 \mathrm{a} \\ \text { C 22:0 } & 0.19 \pm 0.03 & \text { nd } & \text { nd } \\ \text { C 24:0 } & 0.10 \pm 0.07 \mathrm{~b} & \text { nd } & 0.04 \pm 0.01 \mathrm{a}\end{array}$

Mono-unsaturated (MUFA)

$\begin{array}{llll}\text { C } 14: 1 & \text { nd } & \text { nd } & 0.10 \pm 0.01 \\ \text { C 16:1 } & 25.68 \pm 0.55 \mathrm{a} & 33.94 \pm 1.11 \mathrm{c} & 30.16 \pm 1.63 \mathrm{~b} \\ \text { C } 17: 1 & 0.88 \pm 0.01 \mathrm{a} & 1.63 \pm 0.13 \mathrm{~b} & 2.47 \pm 0.07 \mathrm{c} \\ \text { C } 18: 1 \omega-9 \mathrm{t} & 1.20 \pm 0.07 \mathrm{a} & 1.91 \pm 0.14 \mathrm{~b} & \text { nd } \\ \text { C } 18: 1 \omega-9 \mathrm{c} & 8.60 \pm 0.13 \mathrm{~b} & 3.37 \pm 1.01 \mathrm{a} & 4.31 \pm 0.12 \mathrm{a} \\ \text { C } 24: 1 \omega-9 & 0.40 \pm 0.15 \mathrm{a} & 0.81 \pm 0.20 \mathrm{~b} & 0.59 \pm 0.07 \mathrm{ab}\end{array}$

Polyunsaturated (PUFA)

$\begin{array}{llll}\text { C 18:2 } \omega-6 \mathrm{c} & 2.36 \pm 0.14 \mathrm{a} & 3.10 \pm 0.10 \mathrm{a} & 5.78 \pm 1.00 \mathrm{~b} \\ \text { C 18:3 } \omega-6 & 0.87 \pm 0.06 \mathrm{a} & 1.17 \pm 0.15 \mathrm{~b} & 0.91 \pm 0.04 \mathrm{a} \\ \text { C 20:2 } \omega-6 & 0.82 \pm 0.04 \mathrm{a} & 1.50 \pm 0.02 \mathrm{~b} & 1.75 \pm 0.17 \mathrm{c} \\ \text { C 20:3 } \omega-6 & 0.21 \pm 0.01 \mathrm{a} & 0.32 \pm 0.11 \mathrm{~b} & 0.17 \pm 0.02 \mathrm{a} \\ \text { C 20:4 } \omega-6 \text { (ARA) } & 3.00 \pm 0.36 \mathrm{a} & 4.20 \pm 0.21 \mathrm{~b} & 3.11 \pm 0.18 \mathrm{a} \\ \text { C 20:5 } \omega-3 \text { (EPA) } & 7.05 \pm 0.95 \mathrm{a} & 10.20 \pm 0.77 \mathrm{~b} & 15.46 \pm 1.51 \mathrm{c} \\ \text { C 22:2 } \omega-6 & 0.10 \pm 0.01 \mathrm{a} & \text { nd } & 0.15 \pm 0.02 \mathrm{a} \\ \text { C 22:6 } \omega-3 \text { (DHA) } & 0.69 \pm 0.14 \mathrm{a} & 1.23 \pm 0.08 \mathrm{~b} & 1.52 \pm 0.30 \mathrm{~b} \\ \sum \text { SFA } & 47.97 \pm 1.49 \mathrm{~b} & 37.07 \pm 0.17 \mathrm{ab} & 33.51 \pm 1.36 \mathrm{a} \\ \sum \text { MUFA } & 36.70 \pm 0.21 \mathrm{a} & 41.35 \pm 0.43 \mathrm{~b} & 37.64 \pm 1.69 \mathrm{a} \\ \sum \text { PUFA } & 15.28 \pm 1.70 \mathrm{a} & 21.64 \pm 0.80 \mathrm{~b} & 28.85 \pm 3.04 \mathrm{c} \\ \sum \omega 3 & 7.74 \pm 1.08 \mathrm{a} & 11.43 \pm 0.80 \mathrm{~b} & 16.98 \pm 1.79 \mathrm{c} \\ \sum \omega 6 & 7.50 \pm 0.68 \mathrm{a} & 10.21 \pm 0.10 \mathrm{ab} & 11.72 \pm 1.27 \mathrm{~b} \\ \sum \omega 9 & 10.19 \pm 0.35 \mathrm{~b} & 6.08 \pm 1.14 \mathrm{a} & 4.91 \pm 0.06 \mathrm{a}\end{array}$

(Wang et al. 2015). Contrary to our results, temperature stress did not affect the lipid content of the diatom Phaeodactylum tricornutum (Sayanova et al. 2017), although this different behavior could be due to the fact that $P$. tricornutum stress experiments were ended when the cells were at the exponential growth phase.

TAGs are the major lipid constituent in several microalgae (Zulu et al. 2018). In diatoms, their maximum production occurs under adverse environmental conditions, such as nutrient deficiency or low temperature (Yu et al. 2009; Boelen et al. 2017; Wang et al. 2019). TAG accumulation in C. closterium
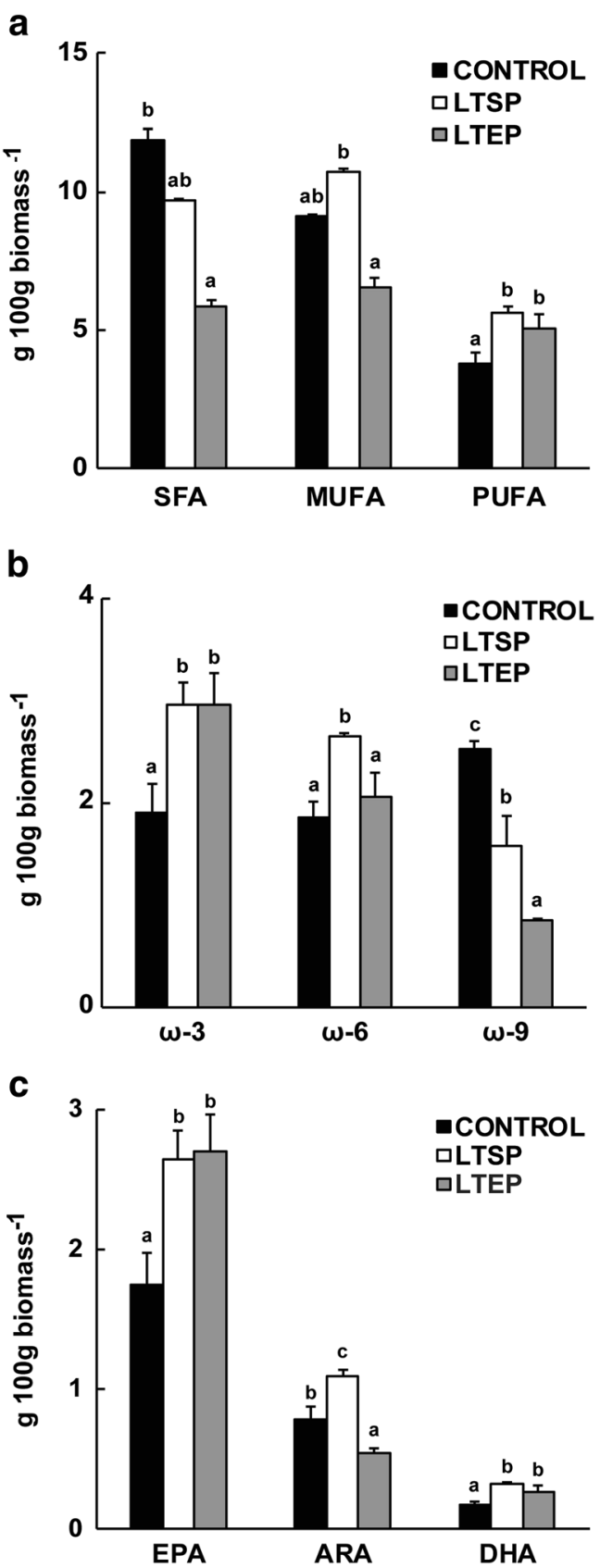

Fig. 4 Analysis of the fatty acid production of C. closterium. The results, expressed as gram fatty acid ( $\mathrm{g}$ ) in $100 \mathrm{~g}$ of biomass, are shown as a saturated (SFA), mono-unsaturated (MUFA) and polyunsaturated (PUFA) fatty acids; b omega 3, 6, and 9 fatty acids; and $\mathbf{c}$ eicosapentaenoic (EPA), arachidonic (ARA), and docosahexaenoic (DHA) fatty acids for C. closterium cells under control, LTSP (low-temperature stress at stationary phase), and LTEP (low-temperature stress at exponential phase). Conversion factor (F) used were 0.88 for control and LTEP conditions and 0.90 for LTSP condition. Values are presented as an average \pm standard deviation ( $n=3$ ). Different letters represent significant differences $(p<0.05)$ between growth conditions for each fatty acid mentioned

followed the expected behavior, reaching the highest lipid value at the stationary growth phase. In addition, low temperature induced TAG accumulation over the control condition. 
Table 3 Saturated (SFAs), mono-unsaturated (MUFAs), and polyunsaturated (PUFAs) fatty acid composition of C. closterium lipid fractions. Lipid fraction: NL (neutral lipid); GL (glycolipids); PL (phospholipids). Control, LTSP (low-temperature stress at stationary phase), LTEP (lowtemperature stress at exponential phase). Values are presented as average \pm standard deviation $(n=3)$. To estimate fatty acid production (expressed as $\left.\mathrm{mg}(100 \mathrm{~g} \text { biomass })^{-1}\right)$ the conversion factor $(\mathrm{F})$ used for control, LTSP, and LTEP conditions, respectively, were LN: $0.73,0.79$, and 0.71; GL: 0.12, 0.09, and 0.13; and PL: 0.04, 0.03, and 0.04. Different letters (per lipid class) represent statistically significant differences $(p<0.05)$

\begin{tabular}{|c|c|c|c|c|c|c|}
\hline \multicolumn{3}{|l|}{ Control } & \multicolumn{2}{|l|}{ LTSP } & \multicolumn{2}{|l|}{ LTEP } \\
\hline \multicolumn{2}{|c|}{$\%$ of total FAMEs } & \multirow[t]{2}{*}{$\mathrm{mg}(100 \mathrm{~g} \text { biomass })^{-1}$} & \multirow[t]{2}{*}{$\%$ of total FAMEs } & \multirow[t]{2}{*}{$\mathrm{mg}(100 \mathrm{~g} \text { biomass })^{-1}$} & \multirow[t]{2}{*}{$\%$ of total FAMEs } & \multirow[t]{2}{*}{$\mathrm{mg}(100 \mathrm{~g} \text { biomass })^{-1}$} \\
\hline NL & & & & & & \\
\hline SFA & $46.09 \pm 0.27 \mathrm{c}$ & $7120 \pm 42.25 b$ & $41.74 \pm 0.34 b$ & $7770 \pm 63.54 c$ & $36.52 \pm 0.52 \mathrm{a}$ & $3860 \pm 55.25 \mathrm{a}$ \\
\hline MUFA & $38.76 \pm 0.29 \mathrm{a}$ & $5990 \pm 45.02 b$ & $44.51 \pm 0.22 \mathrm{c}$ & $8290 \pm 41.42 c$ & $42.17 \pm 0.25 b$ & $4460 \pm 27.18 \mathrm{a}$ \\
\hline PUFA & $15.14 \pm 0.03 \mathrm{~b}$ & $2340 \pm 5.25 \mathrm{a}$ & $13.74 \pm 0.51 \mathrm{a}$ & $2554 \pm 86.23 b$ & $21.31 \pm 0.69 \mathrm{c}$ & $2250 \pm 73.58 \mathrm{a}$ \\
\hline \multicolumn{7}{|l|}{ GL } \\
\hline SFA & $50.52 \pm 0.93 c$ & $327 \pm 6.01 \mathrm{c}$ & $42.53 \pm 0.37 b$ & $149 \pm 1.20 \mathrm{a}$ & $40.32 \pm 1.64 a$ & $203 \pm 8.25 b$ \\
\hline MUFA & $30.02 \pm 0.66 \mathrm{a}$ & $195 \pm 4.25 \mathrm{c}$ & $33.51 \pm 0.62 b$ & $116 \pm 2.19 \mathrm{a}$ & $30.07 \pm 1.06 \mathrm{a}$ & $151 \pm 5.35 b$ \\
\hline PUFA & $19.45 \pm 0.53 \mathrm{a}$ & $126 \pm 3.44 \mathrm{ab}$ & $22.71 \pm 0.32 \mathrm{ab}$ & $79 \pm 1.02 \mathrm{a}$ & $26.61 \pm 2.68 \mathrm{c}$ & $149 \pm 13.47 b$ \\
\hline \multicolumn{7}{|l|}{ PL } \\
\hline SFA & $47.32 \pm 2.68 \mathrm{a}$ & $24 \pm 1.48 b$ & $42.67 \pm 1.83 \mathrm{a}$ & $14 \pm 0.58 \mathrm{a}$ & $43.82 \pm 0.54 a$ & $18 \pm 0.23 \mathrm{ab}$ \\
\hline MUFA & $39.29 \pm 1.51 \mathrm{a}$ & $20 \pm 0.77 b$ & $39.31 \pm 1.29 \mathrm{a}$ & $11 \pm 0.31 \mathrm{a}$ & $36.61 \pm 0.42 \mathrm{a}$ & $15 \pm 0.18 \mathrm{ab}$ \\
\hline PUFA & $13.40 \pm 1.18 \mathrm{a}$ & $7 \pm 0.60 \mathrm{a}$ & $21.35 \pm 1.45 b$ & $7 \pm 0.45 \mathrm{a}$ & $19.57 \pm 0.12 b$ & $8 \pm 0.05 b$ \\
\hline
\end{tabular}

Table 4 Essential fatty acid content of $C$. closterium lipid fractions at control, LTSP, and LTEP conditions. Essential fatty acids: $\omega-3$ (omega3); $\omega-6$ (omega-6); EPA (eicosapentaenoic); ARA (arachidonic); DHA (docosahexaenoic). Lipid fraction: NL (neutral lipid); GL (glycolipids); PL (phospholipids). To estimate fatty acid production (expressed in $\mathrm{mg}$ $\left.(100 \mathrm{~g} \text { biomass })^{-1}\right)$ the conversion factor $(\mathrm{F})$ used for control, LTSP and LTEP conditions, respectively, were LN: $0.73,0.79$, and 0.71 ; GL: 0.12 , 0.09, and 0.13; and PL: 0.04, 0.03, and 0.04. Values are the average \pm standard deviation $(n=3)$. Different letters represent significant differences $(p<0.05)$ between conditions

\begin{tabular}{|c|c|c|c|c|c|c|}
\hline \multicolumn{3}{|l|}{ Control } & \multicolumn{2}{|l|}{ LTSP } & \multicolumn{2}{|l|}{ LTEP } \\
\hline \multicolumn{2}{|c|}{$\%$ of total FAMEs } & \multirow[t]{2}{*}{$\mathrm{mg}(100 \mathrm{~g} \text { biomass })^{-1}$} & \multirow[t]{2}{*}{$\%$ of total FAMEs } & \multirow[t]{2}{*}{$\mathrm{mg}(100 \mathrm{~g} \text { biomass })^{-1}$} & \multirow[t]{2}{*}{$\%$ of total FAMEs } & \multirow[t]{2}{*}{$\mathrm{mg}(100 \mathrm{~g} \text { biomass })^{-1}$} \\
\hline NL & & & & & & \\
\hline$\omega-3$ & $7.72 \pm 0.11 \mathrm{a}$ & $1190 \pm 16.98 \mathrm{a}$ & $7.34 \pm 0.38 \mathrm{a}$ & $1370 \pm 71.07 \mathrm{ab}$ & $13.80 \pm 0.72 b$ & $1440 \pm 75.48 b$ \\
\hline$\omega-6$ & $7.42 \pm 0.08 b$ & $1150 \pm 12.46 b$ & $6.40 \pm 0.16 \mathrm{a}$ & $1190 \pm 23.02 b$ & $7.55 \pm 0.18 b$ & $810 \pm 20.89 a$ \\
\hline EPA & $7.10 \pm 0.11 \mathrm{a}$ & $1097 \pm 13.77 \mathrm{a}$ & $6.73 \pm 0.33 a$ & $1252 \pm 62.15 b$ & $12.67 \pm 0.68 b$ & $1339 \pm 72.25 b$ \\
\hline DHA & $0.59 \pm 0.05 \mathrm{a}$ & $91 \pm 3.20 \mathrm{a}$ & $0.60 \pm 0.04 \mathrm{a}$ & $111 \pm 6.54 b$ & $0.93 \pm 0.07 \mathrm{~b}$ & $98 \pm 7.14 \mathrm{ab}$ \\
\hline ARA & $2.92 \pm 0.08 \mathrm{c}$ & $451 \pm 1.37 \mathrm{~b}$ & $2.70 \pm 0.07 b$ & $502 \pm 13.12 b$ & $2.18 \pm 0.18 \mathrm{a}$ & $230 \pm 19.46 a$ \\
\hline \multicolumn{7}{|l|}{ GL } \\
\hline$\omega-3$ & $6.34 \pm 0.29 a$ & $41 \pm 1.88 b$ & $8.70 \pm 0.27 b$ & $30 \pm 0.93 \mathrm{a}$ & $12.12 \pm 0.95 c$ & $61 \pm 4.78 c$ \\
\hline$\omega-6$ & $13.12 \pm 0.30 \mathrm{a}$ & $85 \pm 1.91 b$ & $14.01 \pm 0.14 \mathrm{ab}$ & $49 \pm 0.39 a$ & $17.48 \pm 1.89 b$ & $88 \pm 9.50 b$ \\
\hline EPA & $6.08 \pm 0.29 \mathrm{a}$ & $39 \pm 1.79 b$ & $8.39 \pm 0.19 b$ & $29 \pm 0.65 a$ & $11.70 \pm 0.88 \mathrm{c}$ & $59 \pm 4.42 c$ \\
\hline DHA & $0.26 \pm 0.16 a$ & $2 \pm 0.13 b$ & $0.31 \pm 0.09 \mathrm{a}$ & $1 \pm 0.30 \mathrm{a}$ & $0.42 \pm 0.07 \mathrm{a}$ & $2 \pm 0.37 \mathrm{~b}$ \\
\hline ARA & $2.12 \pm 0.30 \mathrm{~b}$ & $7 \pm 0.49 b$ & $1.90 \pm 0.04 b$ & $7 \pm 1.32 \mathrm{a}$ & $1.38 \pm 0.17 \mathrm{a}$ & $7 \pm 0.83 \mathrm{a}$ \\
\hline \multicolumn{7}{|l|}{ PL } \\
\hline$\omega-3$ & $6.00 \pm 0.89 a$ & $3 \pm 0.53 a$ & $11.81 \pm 0.58 \mathrm{~b}$ & $4 \pm 0.18 \mathrm{ab}$ & $12.32 \pm 0.03 b$ & $5 \pm 0.02 b$ \\
\hline$\omega-6$ & $7.39 \pm 0.32 \mathrm{a}$ & $4 \pm 0.19 b$ & $9.54 \pm 0.89 b$ & $3 \pm 0.30 \mathrm{a}$ & $7.25 \pm 0.08 \mathrm{a}$ & $3 \pm 0.03 a$ \\
\hline EPA & $4.27 \pm 0.89 \mathrm{a}$ & $2 \pm 0.38 \mathrm{a}$ & $7.68 \pm 0.47 b$ & $2 \pm 0.15 \mathrm{a}$ & $8.54 \pm 0.09 b$ & $4 \pm 0.04 b$ \\
\hline DHA & $1.73 \pm 0.76 \mathrm{a}$ & $1 \pm 0.08 \mathrm{a}$ & $4.13 \pm 0.69 b$ & $1 \pm 0.22 \mathrm{a}$ & $3.79 \pm 0.13 b$ & $2 \pm 0.05 b$ \\
\hline ARA & $3.81 \pm 0.32 \mathrm{a}$ & $2 \pm 0.15 b$ & $4.84 \pm 0.58 \mathrm{a}$ & $1 \pm 0.01 \mathrm{a}$ & $3.83 \pm 0.21 \mathrm{a}$ & $1 \pm 0.09 \mathrm{a}$ \\
\hline
\end{tabular}


Table 5 Comparison between the fatty acids of C. closterium stressed at stationary growth phase and fish oils. Fatty acids are expressed as $\%$ of total FAMEs. Values are presented as average \pm standard deviation $(n=$ 3). *From De Silva et al. (2011)

\begin{tabular}{llllll}
\hline & Anchovy* & Herring* & Capelin* & Menhaden* & C. closterium \\
\hline EPA & $7.6-22.0$ & $3.9-15.2$ & $6.1-8.0$ & $11.1-16.3$ & 10.2 \\
ARA & 0.1 & $<1$ & 0.2 & 0.2 & 4.2 \\
DHA & $9.0-12.7$ & $2.0-7.8$ & $3.7-6.0$ & $4.8-13.8$ & 1.2 \\
\hline
\end{tabular}

Therefore, low temperature acted as a stressor as defined by Borowitzka (2018). Moreover, the temperature did not affect C. closterium lipid fraction distribution, as neutral lipids continued to be the main lipid fraction. These results agree with those reported for other diatoms grown under different stress conditions, in which neutral lipids were the most abundant (Popovich et al. 2012; Yang et al. 2017).

An increase in PUFAs such as EPA and DHA is able to reverse the reduction in cell membrane fluidity that occurs with exposure to low temperatures (Aussant et al. 2018). In this connection and in line with other reports on marine diatoms (Mortensen et al. 1988; Chen 2012; Pasquet et al. 2014), in C. closterium, low temperature induced a significant rise in long-chain PUFAs. This effect was also observed in Thalassiosira pseudonana, Chaetoceros calcitrans, Chaetoceros simplex, Chaetoceros gracilis, and $P$. tricornutum. These diatoms showed higher PUFA and lower SFA contents when cells were adapted to grow at $10^{\circ} \mathrm{C}$ than when they grew at $25^{\circ} \mathrm{C}$ (Thompson et al. 1992). In addition, Jiang and Gao (2004) reported in P. tricornutum that the relative amount of PUFAs significantly increased from 12 to $20 \%$ in response to low-temperature stress. This effect was observed after 3 days of thermal stress, suggesting that the mechanisms involved in the response to low-temperature stress are very fast (Sayanova et al. 2017). Ryckebosch et al. (2014) reported in P. tricornutum and T. pseudonana higher EPA and DHA contents in the NL fraction (\% of total FAMEs) than those found in C. closterium in this study. Our results show that both temperature treatments (LTSP and LTEP) induced an increase in the level of EPA ( $\%$ of total FAMEs) in the polar lipid fraction. This is consistent with the report of Chen et al. (2008), suggesting that EPA is the main FA of the
Fig. 5 Analysis of C. closterium sterols. a Spectrophotometric determination of the total content of sterols in C. closterium (expressed as $\mathrm{mg} \mathrm{L}^{-1}$ ) at 2, 4, 7, and 10 days of culture under control, LTSP, and LTEP temperature conditions. $\mathbf{b}$ Gas chromatography analysis of the sterol profile of C. closterium cells at the end of each temperature condition (control, LTSP, and LTEP) expressed as \% of sterols. Insert: relative amounts of total phytosterols and cholesterol at different growth conditions. Values are presented as average \pm standard deviation $(n=3)$. Different letters represent significant differences $(p<0.05)$ a

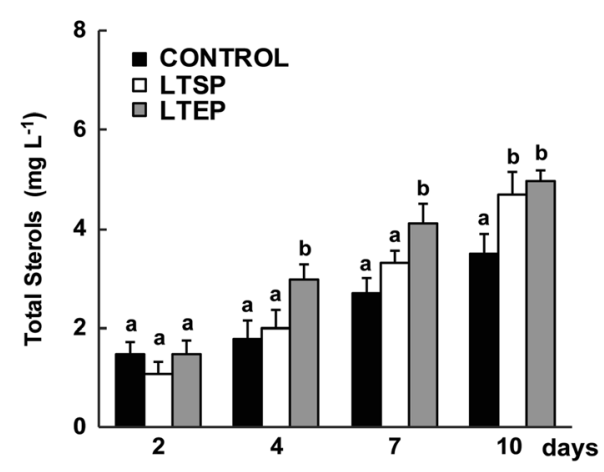

b

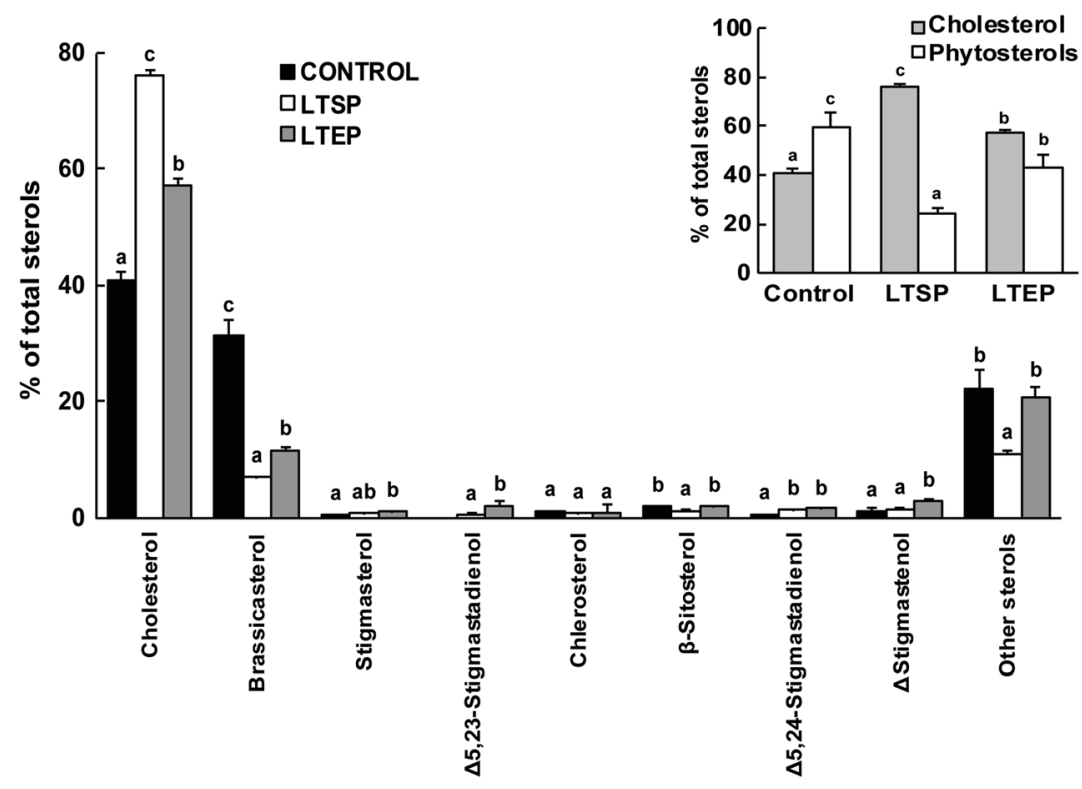




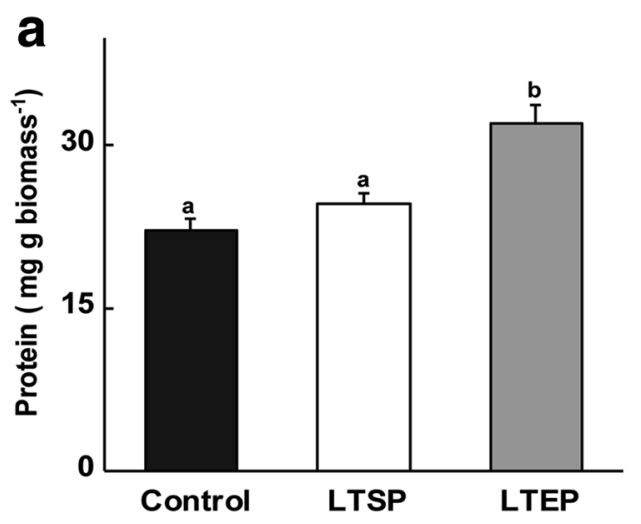

Fig. 6 Protein content and amino acid composition of C. closterium. a Protein content ( $\mathrm{mg} \mathrm{g}^{-1}$ biomass) for control, LTSP and LTEP growth conditions. Different letters represent statistically significant differences $(p<0.05)$ between conditions. b Percentage of essential (EAA),

polar fraction when cells are exposed to low culture temperature. However, since polar lipids are a minor lipid fraction, they are not relevant in terms of PUFA production. In $C$. closterium we detected an increase in the relative amount of EPA in the NL fraction only when the temperature was lowered at the exponential growth phase. This may be due to the fact that TAG-containing lipid droplets are synthetized

Table 6 Amino acid composition (\% of total amino acids) of C. closterium for the LTSP thermal stress condition. Values are presented as average \pm standard deviation $(n=$ 3). *Essential (EAA), conditionally essential (CEAA), and nonessential (NEAA) amino acids for aquatics animals (Li et al. 2009)

\begin{tabular}{lc}
\hline Amino acids (AA) & $\%$ of total AA \\
\hline Essential AA* & \\
Arginine & $5.40 \pm 0.08$ \\
Histidine & $3.10 \pm 0.01$ \\
Isoleucine & $4.49 \pm 0.35$ \\
Leucine & $7.83 \pm 0.17$ \\
Lysine & $6.01 \pm 0.01$ \\
Methionine & $2.67 \pm 0.04$ \\
Phenylalanine & $6.07 \pm 0.17$ \\
Threonine & $5.04 \pm 0.23$ \\
Tryptophan & nd \\
Valine & $6.19 \pm 0.57$ \\
Conditionally essential AA* \\
Cysteine & $1.52 \pm 0.01$ \\
Glutamine & nd \\
Hydroxyproline & nd \\
Proline & $6.62 \pm 1.30$ \\
Taurine & nd \\
Non-essential AA* & \\
Alanine & $6.84 \pm 0.40$ \\
Asparagine & $5.59 \pm 0.14$ \\
Aspartate & $6.56 \pm 0.32$ \\
Glutamate & $4.43 \pm 0.04$ \\
Glycine & \\
Serine & \\
Tyrosine & \\
\hline & \\
\hline
\end{tabular}

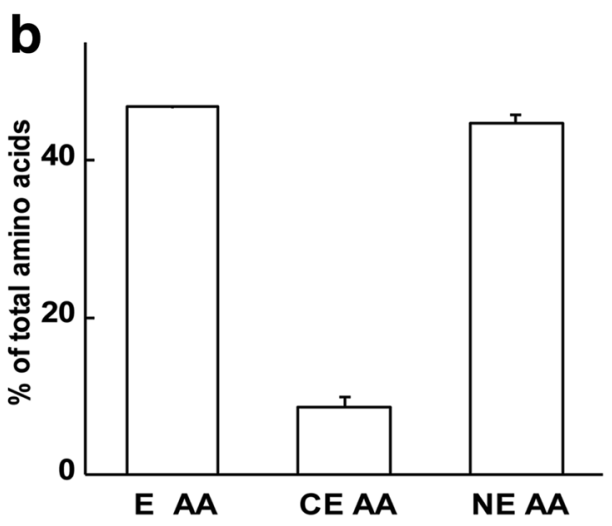

conditionally essential (CEAA), and non-essential amino acids (NEAA) for aquatic animals (Li et al. 2008) of $C$. closterium under LTSP growth condition. Values are presented as average \pm standard deviation $(n=3)$

during low-temperature stress using unsaturated FAs. However, when the temperature is lowered at the stationary growth phase, lipid droplets have already been formed so their EPA content cannot be modified.

An increase in the \% of total FAMEs does not necessarily imply an increase in FA production in terms of biomass. Boelen et al. (2017) reported that although Skeletonema costatum showed higher EPA content than T. pseudonana $\approx 20 \%$ of total FAMEs against $\approx 8 \%$ of total FAMEs), normalizing these values to take into account the biovolume ( $\mathrm{fg} \mathrm{\mu m}^{-3}$ ) showed EPA to be 9 times more abundant in T. pseudonana than in S. costatum. In this regard, when we expressed the FA contents of $C$. closterium in terms of biomass, we arrived at the conclusion that neutral lipids were the main fraction contributing to EPA, DHA, and ARA production. It thus follows that the best cultivation strategy for achieving essential FA production would be to lower the temperature at the beginning of the stationary growth phase. The results obtained in $C$. closterium with respect to $\omega-3$ FA content are similar to those reported for $P$. tricornutum, with values of 2960 and $2945 \mathrm{mg}$ (100 g biomass $)^{-1}$, respectively. Nevertheless, $\omega-6$ FAs were more abundant in $C$. closterium $\left(2648 \mathrm{mg}(100 \mathrm{~g} \text { biomass })^{-1}\right)$ than in P. tricornutum $\left(\mathrm{mg}(100 \mathrm{~g} \text { biomass })^{-1}\right.$ ) (Matos et al. 2016). Among microalgae, diatoms contain a large amount of ARA $\omega-6$ FAs (Sanaa et al. 2018). Owing to its role in growth, development and immune function, broodstock nutrition and egg and larval quality PUFA are essential for vertebrates (Bell and Sargent 2003; Sanaa et al. 2018). The production of EPA and DHA in C. closterium is consistent with that reported for other microalgal species. However, the production of ARA in C. closterium was much higher than that reported for Chlorella vulgaris $(12 \mathrm{mg}(100 \mathrm{~g}$ biomass $)^{-1}$ ), Haematococcus pluvialis (292 mg (100 g biomass $\left.)^{-1}\right)$ Isochrysis galbana (69 $\left.\mathrm{mg}(100 \mathrm{~g} \text { biomass })^{-1}\right)$ and P. tricornutum (83 mg (100 g biomass) $)^{-1}$ ) (Batista et al. 2013; Matos et al. 2016; Bonfanti et al. 2018). On the other hand, EPA production in C. closterium was higher than that reported for I. galbana (276 $\left.\mathrm{mg}(100 \mathrm{~g} \text { biomass })^{-1}\right)$ and similar to that 
reported for P. tricornutum (2753 $\left.\mathrm{mg}(100 \mathrm{~g} \text { biomass })^{-1}\right)$, while DHA production was higher than in $P$. tricornutum $(80 \mathrm{mg}$ $\left.(100 \mathrm{~g} \text { biomass })^{-1}\right)$ and much lower than in I. galbana $\left(2146 \mathrm{mg}(100 \mathrm{~g} \text { biomass) })^{-1}\right.$ ) (Matos et al. 2016; Bonfanti et al. 2018). Our findings therefore support previous studies proposing diatoms as sources of EPA and ARA FAs (Sanaa et al. 2018; Shah et al. 2018). Furthermore, EPA and ARA values of C. closterium under the LTSP growth condition were found to be very similar to those reported for fish oils (De Silva et al. 2011). Induction of C. closterium thermal stress during the stationary growth phase would therefore indicate this to be the strategy of choice for achieving the highest production of total lipids enriched in PUFAs.

Diatoms, when grown under stress conditions, can produce diverse amounts of sterols (Ballantine et al. 1979; Ryckebosch et al. 2014; Volkman 2016). In the present study, a decrease in culture temperature was shown to give rise to an increase in the synthesis of sterols in C. closterium. Véron et al. (1996) reported similar results related to the effect of temperature on the sterol content in P. tricornutum. However, Piepho et al. (2012) observed in Cyclotella meneghiniana that sterol concentrations were higher at $25^{\circ} \mathrm{C}$ than at $10^{\circ} \mathrm{C}$.

In terms of sterol composition, the main sterol found in C. closterium was cholesterol (75\% of total sterols in the LTSP condition), while small amounts of phytosterols were detected. These results are in agreement with those obtained in Nitzschia closterium and the eustigmatophyte Nannochloropsis oculata, where the dominant sterol was cholesterol (Volkman et al. 1992; Barrett et al. 1995). Although the presence of cholesterol in the human diet is associated with an increased risk of atherosclerosis and coronary thrombosis (Attia et al. 2015), its presence in fish diets is necessary (Barrett et al. 1995; Norambuena et al. 2013; Zhu et al. 2014, 2018). Rampen et al. (2010) characterized the sterol profile of more than 100 diatoms harvested at the end of the logarithmic growth phase. The results reported for $C$. closterium were similar to ours, as they identified the following sterols: Cholest-5-en-3 $\beta$-ol (cholesterol), 24methylcholesta-5,24(28)-dien-3 $\beta$-ol (brassicasterol) and 24ethylcholesta-5,24(28Z)-dien-3 $\beta$-ol ( $\Delta$-5-24 stigmastadienol), representing $92 \%, 5 \%$, and $3 \%$ of the total sterol content, respectively.

Proteins are essential nutrients for fish as a source of nitrogen and dietary protein is one of the major and most expensive components of formulated aquafeeds ( $\mathrm{Li}$ et al. 2009). Amino acids are the building blocks of proteins and some of them, known as essential amino acids, cannot be synthetized by fish and so must be provided by the diet (Cowey 1994). We observed that under the LTEP condition, the protein content in C. closterium was higher than that under the LTSP condition. However, as the LTSP condition exhibited the best production in terms of essential FAs, we selected this condition for the amino acid profile analysis. Nine of the ten essential amino acids for aquatic animals were found, suggesting that
C. closterium proteins produced after lowering culture temperature at the stationary growth phase are of good quality ( $\mathrm{Li}$ et al. 2009). This amino acid profile resulted is very similar to that reported by Brown (1991) for different species of diatoms.

\section{Conclusion}

Our results show that low-temperature stress induced during the stationary growth phase of Cylindrotheca closterium is an appropriate strategy to (1) increase biomass production, (2) increase total lipid production, and (3) increase the production of essential fatty acids. Furthermore, the rapid response of C. closterium to low-temperature stress suggests that this could be an appropriate strategy for productive processes. The basic information provided in this paper constitutes a valuable input in the search for the alternative and sustainable production of PUFAs, sterols and essential amino acids. One of the remaining challenges is to develop larger scale productive systems which are economically viable and have an effective temperature control for inducing thermal stress.

Acknowledgments Fatty acids and sterol analyses where carried out in PLAPIQUI (CONICET-UNS) and supported by Universidad Nacional del Sur (PGI M24/152) to DC. The technical assistance by Dra. M. Cecilia Damiani, Dr. Federico Delucchi, and Jorge Oyola is acknowledged. MDA is a Fellow Member of CONICET. PGSB and PIL are Research Members of CONICET. DC is a Professional Support of CONICET. CAP is a Research Member of Comisión de Investigaciones Científicas de la Provincia de Buenos Aires. The funders had no role in study design, data collection and analysis, decision to publish, or preparation of the manuscript.

Author contributions All authors participated in the conception and design of experiments. MDA, DC, and CAP performed the temperature experiments in the photobioreactor. MDA, PSB, and DC performed the biochemical analysis. All authors made the interpretation of the data of the article and discussed their results. MDA and PSB wrote the article. PIL, CAP, and DC made the critical revision of the article contributing with intellectual content. All authors finally approved the article submission.

Funding information This research was supported by grants from Agencia Nacional de Promoción Científica y Tecnológica to PGSB (PICT 2014-0893) and PIL (PICT 2015-0800); Consejo Nacional de Investigaciones Científicas y Técnicas de la República Argentina (CONICET, PIP 112-2015 01-00510) and Universidad Nacional del Sur (PGI 24/B246) to PIL.

\section{References}

Adarme-Vega TC, Lim DKY, Timmins M, Vernen F, Li Y, Schenk PM (2012) Microalgal biofactories: a promising approach towards sustainable omega-3 fatty acid production. Microb Cell Factories 11:96

Attia JA, Al-Harthi MA, Korish MA, Shiboob MM (2015) Fatty acid and cholesterol profiles and hypocholesterolemic, atherogenic, and 
thrombogenic indices of table eggs in the retail market. Lipids Health Dis 14:136

Aussant J, Guihéneuf F, Stengel DB (2018) Impact of temperature on fatty acid composition and nutritional value in eight species of microalgae. Appl Microbiol Biotechnol 102:5279-5297

Ballantine JA, Lavis A, Morris RJ (1979) Sterols of the phytoplanktoneffects of illumination and growth stage. Phytochemistry 18:14591466

Barrett SM, Volkman JK, Dunstan GA, LeRoi JM (1995) Sterols of 14 species of marine diatoms (Bacillariophyta). J Phycol 31:360-369

Batista AP, Gouveia L, Bandarra NM, Franco JM, Raymundo A (2013) Comparison of microalgal biomass profiles as novel functional ingredient for food products. Algal Res 2:164-173

Bell JG, Sargent JR (2003) Arachidonic acid in aquaculture feeds: current status and future opportunities. Aquaculture 218:491-499

Boelen P, Mastrigt AV, Van de Bovenkamp HH, Heeres HJ, Buma AGJ (2017) Growth phase significantly decreases the DHA-to-EPA ratio in marine microalgae. Aquac Int 25:577-587

Bonfanti C, Cardoso C, Afonso C, Matos J, Garcia T, Tanni S, Bandarra NM (2018) Potential of microalga Isochrysis galbana: bioactivity and bioaccessibility. Algal Res 29:242-248

Borowitzka MA (2018) The 'stress' concept in microalgal biology-homeostasis, acclimation and adaptation. J Appl Phycol 30:2815-2825

Bozarth A, Maier UG, Zauner Z (2009) Diatoms in biotechnology: modern tools and applications. Appl Microbiol Biotechnol 82:195-201

Bradford MM (1976) A rapid and sensitive method for the quantitation of microgram quantities of protein utilizing the principle of protein-dye binding. Anal Biochem 72:248-254

Brown MR (1991) The amino-acid and sugar composition of 16 species of microalgae used in mariculture. J Exp Mar Biol Ecol 145:79-99

Camacho-Rodríguez J, Macías-Sánchez MD, Cerón-García MC, Alarcón FJ, Molina-Grima E (2018) Microalgae as a potential ingredient for partial fish meal replacement in aquafeeds: nutrient stability under different storage conditions. J Appl Phycol 30:1049-1059

Chen G, Jiang Y, Chen F (2008) Fatty acid and lipid class composition of the eicosapentaenoic acid-producing microalga, Nitzschia laevis. Food Chem 104:1580-1585

Chen YC (2012) The biomass and total lipid content and composition of twelve species of marine diatoms cultured under various environments. Food Chem 131:211-219

Cowey CB (1994) Amino acid requirements of fish: a critical appraisal of present values. Aquaculture 124:1-11

De Silva S, Francis DS, Tacon AGJ (2011) Fish oil in aquaculture: in retrospect. In: Turchini GM, Ng WK, Tocher DR (eds) Fish oil replacement and alternative lipid sources in aquaculture feeds. CRC Press, Boca Raton, pp 1-20

Demirel Z (2016) Identification and fatty acid composition of coccolithophore and diatom species isolated from Aegean Sea. Rom Biotech Lett 21:11746-11753

Di Rienzo JA, Casanoves F, Balzarini MG, Gonzalez L, Tablada M, Robledo CW (2018) Group InfoStat, FCA, University National of Córdoba, Argentina URL http://www.infostat.com.ar

Duong VT, Thomas-Hall SR, Schenk PM (2015) Growth and lipid accumulation of microalgae from fluctuating brackish and sea water locations in South East Queensland-Australia. Front Plant Sci 6: 359

Erdoğan A, Demirel Z, Dalay MC, Eroğlu AE (2016) Fucoxanthin content of Cylindrotheca closterium and its oxidative stress mediated enhancement. Turk J Fish Aquat Sci 16:489-497

FAO (2018) The state of world fisheries and aquaculture 2018. Meeting the sustainable development goals. FAO, Rome

Folch J, Lees M, Sloane Stanley GH (1957) A simple method for the isolation and purification of total lipids from animal tissues. J Biol Chem 226:497-509

Gong Y, Bandara T, Huntley M, Johnson ZI, Dias J, Dahle D, Sorensen M, Kiron V (2019) Microalgae Scenedesmus sp. as a potential ingredient in low fishmeal diets for Atlantic salmon (Salmo salar). Aquaculture 501:455-464

Guillard RRL (1973) Division rates. In: Stein JR (ed) Handbook of phycological methods: culture methods and growth measurements. Cambridge University Press, Cambridge, pp 289-311

Hasle GR, Syvertsen EE (1997) Marine diatoms. In: Tomas CR (ed) Identifying marine phytoplankton. Academic Press, San Diego, pp $5-385$

Hamilton ML, Haslam RP, Napier JA, Sayanova O (2014) Metabolic engineering of Phaeodactylum tricornutum for the enhanced accumulation of omega-3 long chain polyunsaturated fatty acids. Metab Eng 22:3-9

Hillebrand H, Dürselen DC, Kirschtel D, Pollingher U, Zohary T (1999) Biovolume calculation for pelagic and benthic microalgae. J Phycol 35:403-424

International Olive Council (2001) Determination of the composition and content of sterols by capillary-column gas chromatography. COI/ T.20/Doc. No. 10/Rev. 1. http://www.internationaloliveoil.org

Jiang H, Gao K (2004) Effects of lowering temperature during culture on the production of polyunsaturated fatty acids in the marine diatom Phaeodactylum tricornutum (Bacillariophyceae). J Phycol 40:651654

Lazzarotto V, Médale F, Larroquet L, Corraze G (2018) Long-term dietary replacement of fishmeal and fish oil in diets for rainbow trout (Oncorhynchus mykiss): effects on growth, whole body fatty acids and intestinal and hepatic gene expression. PLoS One 13:e0190730

Li P, Mai K, Trushenski J, Wu G (2009) New developments in fish amino acid nutrition: towards functional and environmentally oriented aquafeeds. Amino Acids 37:43-53

Liang Y, Mai K, Sun S (2002) Effects of harvest stage on the total lipid and fatty acid composition of four Cylindrotheca strains. Chin J Oceanol Limnol 20:157-161

Lombardi AT, Wangersky PJ (1995) Particulate lipid class composition of three marine phytoplankters Chaetoceros gracilis, Isochrysis galbana (Tahiti) and Dunaliella tertiolecta grown in batch culture. Hydrobiologia 306:1-6

López Alonso D, Belarbib E, Fernández-Sevilla JM, Rodríguez-Ruiz J, Molina Grima E (2000) Acyl lipid composition variation related to culture age and nitrogen concentration in continuous culture of the microalga Phaeodactylum tricornutum. Phytochemistry 55:461471

Luo X, Su P, Zhang W (2015) Advances in microalgae-derived phytosterols for functional food and pharmaceutical applications. Mar Drugs 13:4231-4254

Maisashvili A, Bryant H, Richardson J, Anderson D, Wickersham T, Drewery M (2015) The values of whole algae and lipid extracted algae meal for aquaculture. Algal Res 3:133-142

Martín LAL, Popovich CA, Martinez AM, Damiani MC, Leonardi PI (2016) Oil assessment of Halamphora coffeaeformis diatom growing in a hybrid two-stage system for biodiesel production. Renew Energy 92:127-135

Matos AP, Feller R, Moecke EHS, De Oliveira JV, Junior AF, Bianchini Derner R, Sant'Anna ES (2016) Chemical characterization of six microalgae with potential utility for food application. J Am Oil Chem Soc 93:963-972

McLachlan JL (1973) Growth media-marine. In: Stein JR (ed) Handbook of phycological methods: culture methods and growth measurements. Cambridge University Press, Cambridge, pp 26-47

Miller MR, Peter DN, Carter CG (2008) The digestibility and accumulation of dietary phytosterols in Atlantic Salmon (Salmo salar L.) smolt fed diets with replacement plant oils. Lipids 43:549-557

Montagnes DJS, Franklin M (2001) Effect of temperature on diatom volume, growth rate, and carbon and nitrogen content: reconsidering some paradigms. Limnol Oceanogr 46:2008-2018

Mortensen SH, Børsheim KJ, Rodríguez Rainuzzo J, Knutsen G (1988) Fatty acid and elemental composition of the marine diatom 
Chaetoceros gracilis Schütt. Effects of silicate deprivation, temperature and light intensity. J Exp Mar Biol Ecol 122:173-185

Norambuena F, Lewis M, Hamid NKA, Hermon K, Donald JA, Turchini GM (2013) Fish oil replacement in current aquaculture feed: is cholesterol a hidden treasure for fish nutrition? PLoS One 8:e81705

Pasquet V, Ulmann L, Mimouni V, Guihéneuf F, Jacquette B, MorantManceau A, Tremblin G (2014) Fatty acids profile and temperature in the cultured marine diatom Odontella aurita. J Appl Phycol 26: 2265-2271

Piepho M, Martin-Creuzburg D, Wacker A (2012) Phytoplankton sterol contents vary with temperature, phosphorus and silicate supply: a study on three freshwater species. Eur J Phycol 47:138-145

Popovich CA, Damiani C, Constenla D, Leonardi PI (2012) Lipid quality of the diatoms Skeletonema costatum and Navicula gregaria from the South Atlantic Coast (Argentina): evaluation of its suitability as biodiesel feedstock. J Appl Phycol 24:1-10

Popovich CA, Marcovecchio JE (2008) Spatial and temporal variability of phytoplankton and environmental factors in a temperate estuary of South America (Atlantic Coast, Argentina). Cont Shelf Res 28: 236-244

Qiao H, Cong C, Sun C, Li B, Wang J, Zhang L (2016) Effect of culture conditions on growth, fatty acid composition and DHA/EPA ratio of Phaeodactylum tricornutum. Aquaculture 452:311-317

Rampen SW, Abbas BA, Schouten S, Sinninghe Damsté JS (2010) A comprehensive study of sterols in marine diatoms (Bacillariophyta): implications for their use as tracers for diatom productivity. Limnol Oceanogr 55:91-105

Ryckebosch E, Bruneel C, Termote-Verhalle R, Goiris K, Muylaert K, Foubert I (2014) Nutritional evaluation of microalgae oils rich in omega-3 long chain polyunsaturated fatty acids as an alternative for fish oil. Food Chem 160:393-400

Sanaa MM, Shanab SMM, Hafez RM, Fouad AS (2018) A review on algae and plants as potential source of arachidonic acid. J Adv Res $11: 3-13$

Sayanova O, Mimouni V, Ulmann L, Morant-Manceau A, Pasquet V, Schoefs B, Napier JA (2017) Modulation of lipid biosynthesis by stress in diatoms. Phil Trans Roy Soc B 372:20160407

Scodelaro Bilbao PG, Damiani C, Salvador GA, Leonardi P (2016) Haematococcus pluvialis as a source of fatty acids and phytosterols: potential nutritional and biological implications. J Appl Phycol 28: 3283-3294

Shah MR, Lutzu GA, Alam A, Sarker P, Chowdhury K, Parsaeimehr A, Liang Y, Daroch M (2018) Microalgae in aquafeeds for a sustainable aquaculture industry. J Appl Phycol 30:197-213

Simpson RJ, Neuberger MR, Liu TY (1976) Complete amino acid analysis of proteins from a single hydrolysate. J Biol Chem 251:19361940

Thompson PA, Guo M, Harrison PJ, Whytee JNC (1992) Effects of variation in temperature on the fatty acid composition of eight species of marine phytoplankton. J Phycol 28:488-497

Tocher DR (2015) Omega-3 long-chain polyunsaturated fatty acids and aquaculture in perspective. Aquaculture 449:94-107
Turchini GM, Torstensen BE, Ng WK (2009) Fish oil replacement in finfish nutrition. Rev Aquac 1:10-57

Véron B, Billard C, Dauguet JC, Hartmann MA (1996) Sterol composition of Phaeodactylum tricornutum as influenced by growth temperature and light spectral quality. Lipids 31:989-994

Volkman JK, Barrett SM, Dunstan GA, Jeffrey SW (1992) C30-C32 alkyl diols and unsaturated alcohols in microalgae of the class Eustigmatophyceae. Org Geochem 18:131-138

Volkman JK (2016) Sterols in microalgae. In: Borowitzka MA, Beardall J, Raven J (eds) The physiology of microalgae. Springer, Cham, pp 485-505

Wang S, Zhang L, Yang G, Zhu B, Pan K (2015) Purification of a diatom and its identification to Cylindrotheca closterium. J Ocean Univ China 14:357-361

Wang S, Verma SK, Said IH, Thomsen L, Ullrich MS, Kuhnert N (2018) Changes in the fucoxanthin production and protein profiles in Cylindrotheca closterium in response to blue light-emitting diode light. Microb Cell Factories 17:110-122

Wang S, Sirbu D, Thomsen L, Kuhnert N, Ullrich MS, Thomsen C (2019) Comparative lipidomic studies of Scenedesmus sp. (Chlorophyceae) and Cylindrotheca closterium (Bacillariophyceae) reveal their differences in lipid production under nitrogen starvation. J Phycol 55:1246-1257

Ward OP, Singh A (2005) Omega-3/6 fatty acids: alternative sources of production. Process Biochem 40:3627-3652

Weihrauch JI, Posati LP, Anderson BA, Exler J (1977) Lipid conversion factors for calculating fatty acid contents of foods. J Am Oil Chem Soc 54:36-40

Yang YJ, Du L, Hosokawa M, Miyashita K, Kokubun Y, Arai H, Taroda H (2017) Fatty acid and lipid class composition of the microalga Phaeodactylum tricornutum. J Oleo Sci 66:363-368

Yao L, Gerde JA, Lee SL, Wang T, Harrata KA (2015) Microalgae lipid characterization. J Agric Food Chem 63:1773-1787

Yi Z, Xu M, Di X, Brynjolfsson S, Fu W (2017) Exploring valuable lipids in diatoms. Front Mar Sci 4:17

Yu ET, Zendejas FJ, Lane PD, Gaucher S, Simmons BA, Lane TW (2009) Triacylglycerol accumulation and profiling in the model diatoms Thalassiosira pseudonana and Phaeodactylum tricornutum (Baccilariophyceae) during starvation. J Appl Phycol 21:669-681

Zhu T, Ai Q, Mai K, Xu W, Zhou H, Liufu Z (2014) Feed intake, growth performance and cholesterol metabolism in juvenile turbot (Scophthalmus maximus L.) fed defatted fish meal diets with graded levels of cholesterol. Aquaculture 428-429:290-296

Zhu T, Corraze G, Plagnes-Juan E, Quillet E, Dupont-Nivet M, SkibaCassy S (2018) Regulation of genes related to cholesterol metabolism in rainbow trout (Oncorhynchus mykiss) fed a plant-based diet. Am J Physiol Regul Integr Comp Physiol 314:58-70

Zulu NN, Zienkiewicz K, Vollheyde K, Feussner I (2018) Current trends to comprehend lipid metabolism in diatoms. Prog Lipid Res 70:1-16

Publisher's note Springer Nature remains neutral with regard to jurisdictional claims in published maps and institutional affiliations. 